\title{
Analyzing the Effect of Learning Styles and Study Habits of Distance Learners on Learning Performances: A Case of an Introductory Programming Course
}

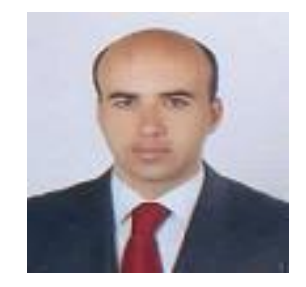

Ünal Çakıroğlu

Karadeniz Technical University, TURKEY

\section{Abstract}

This study examined the relationships among learning styles, study habits, and learning performances in an online programming language course. Sixty-two sophomore students who enrolled in an online introductory programming course participated in the study. Kolb's Learning Style Inventory (LSI) was used to measure the students' learning styles. Another inventory developed by the researcher was used to determine learners' study habits. An achievement test was used to put forward their learning performances. As a result, significant relationships between learning styles, study habits, and learning performances were revealed. The results present some ideas about distance learners' learning styles and study habits for instructors who wish to incorporate synchronous courses and support learners.

Keywords: Learning styles; study habits; learning performances; distance learning; synchronous settings 


\section{Introduction}

To respond to the diverse distance and time needs of today's learners, many institutions offer online courses to expand their teaching methods with distance learning courses. They work on specializing or adapting the courses according to learners' needs (Hamilton-Pennell, 2002). Learners' needs include different learning styles which can influence learning performance (Mitchell, 2000; Chen \& Lin, 2002; Morris, Finnegan, \& Sz-Shyan, 2005; Hummel, 2006).

Definitions of learning style generally focus on ways of learning. According to Fleming (2001) learning style is an individual's preferred way of gathering, organizing, and thinking about information. It is considered as the behaviors related to the psychological, cognitive, and affective domains of interaction with learning environments. Learning style involves learners' preferred ways to receive, process, and recall information during instruction which is related to learners' motivation and information-processing habits (Aragon, J ohnson, \& Shaik, 2002).

Research studies on learning styles have shown that learning can be enhanced through consideration of personal characteristics in design and delivery of the instruction (Dziuban, Moskal, \& Hartman, 2004; Fearing \& Riley, 2005). Because some learners tend to focus on facts, data, or procedures, engaging with theories and mathematical models is appropriate. Other learners use visual information like pictures, diagrams, and simulations to understand better, while others can get more from oral and written information. Researchers have argued that learning style also functions as a useful indicator for potential learning performance (Kolb \& Kolb, 2005; Smith \& Ragan, 1999; Sun et al., 2008). In this context, Dunn and Dunn (1978) stated that students with different learning styles have distinct preferences during different instructional activities. Thus, various models have been proposed by theoreticians and used by educators in order to measure learning styles, and various instruments have been used.

Coffield et al. (2012) provided an extensive report which involved at least 71 learning style models. The models have some components different from each other related to the extent that they may change over time for learners. Some popular instruments were various extensions of J ung's (1970) psychological types and Gardner's (1993) multiple intelligences. One of the widely used models in this area was developed by Gregorc and Butler (1984) which has four combinations of perceptual qualities and ordering abilities: concrete sequential, abstract random, abstract sequential, and concrete random. In this model it is considered that each individual can be strong in one or two of the four styles. As a contrast to Gregorc (1984), Felder and Silverman (1988) did not consider learning styles to be constant. According to them, learning preferences may change due to the time and situation. Fleming's (2001) VARK inventory, which includes visual, aural, read-write, and kinesthetic perceptual styles, and the specific inventory of Felder and Soloman (1997), which measures learning preferences across four bipolar

preferences, active-reflective, sensing-intuitive, visual-verbal, and sequential-global, are well known examples derived from the models above. 
One of the popular learning style inventories for determining adults' learning styles is Kolb's Learning Style Inventory (LSI). It includes four dimensions: concrete experience (feeling), reflective observation (watching), abstract conceptualization (thinking), and active experimentation (doing) (Kolb, 1985). Through four dimensions, Kolb determined four learning styles: accommodative, divergent, convergent, and assimilative.

Many research studies have been conducted using Kolb's inventory in order to determine learning styles. For example, J onassen and Grabowski (1993) in their study suggested that the LSI was more suited to having students explore their learning styles than to predicting their ability to succeed. Terrell (2002) made a comparison of graduation rate by learning style of 216 students. He found most of the students were either convergers or assimilators and the comparison was not statistically significant. In addition, Fahy and Ally (2005) used Kolb's LSI for two online courses including asynchronous discussions. Akkoyunlu and Soylu (2008) revealed that students' views on the blended learning process, such as ease of use of the web environment, evaluation, face to face environment, and so on, differ according to their learning styles.

On the other hand, Honey and Mumford (1986) developed a self-development tool based on Kolb's model by inviting managers to address trainees' learning style preferences. They used the tool on a wide range of higher education students. In this instrument they identified four distinct learning styles: activists, theorists, pragmatists, and reflectors.

\section{Learning Styles in Distance Learning}

Some researchers focused on the learning styles of distance learners. In this sense, Allen et al. (2002) suggested delivering courses in a variety of formats to accommodate multiple learning styles. Benbunan-Fich and Hiltz (2003) deemed it necessary to conduct research into the relationship among learning styles, the chosen mode of delivery, and student success. In another study Liegle and J anicki (2006) investigated the effect of learning styles on the Internet navigation needs of web based learners, finding that students as explorers provided a higher number of visits to linked web pages, whereas observers tended to be more passive. Also a few of the studies focused on academic performances and learning styles. Akdemir and Koszalkab (2008) determined the relationships between instructional strategies and learning styles in an online graduate level course. In the study, although using different kinds of instructional strategies for various learning styles learners' performances were equivalent. In another study, Popescu (2010) studied relationships between web-based educational systems and learning styles and found that accommodators benefited more than others in the learning process. Also, Shaw (2012) found that different learning styles were associated with significantly different learning scores. In addition, Schellens and Valcke (2000) and Neuhauser (2002) did not find such relationships between learning style and learning performance in online learning. 
Furthmore, some studies were conducted in the distance learning area using Kolb's inventory. In one of those studies, Wang et al. (2006) focused on the effects of formative assessment and learning style on student performances in a web-based learning environment. The results showed that both learning style and formative assessment strategy were significant factors affecting student achievement in a web-based learning environment. Sun et al. (2008) used Kolb's inventory for investigating the learning outcomes related to different learning styles in a virtual science laboratory for elementary school students. Students who used the online virtual lab were not significantly different from students of different learning styles. Kolb's LSI was used in other online learning research studies to measure learners' preferences and learning styles (Dringus \& Terrell, 2000; Federico, 2000; Fahy \&Ally, 2005; Miller, 2005; Liegle \&J anicki, 2006; Wang et al., 2006; Lu et al., 2007) .

\section{Study Habits}

Study habits act as another variable connected with distance learners' performances. Study habits reflect students' usual act of studying and also call forth and serve to direct the learner's cognitive processes during learning. Study habits includes a variety of activities: time management, setting appropriate goals, choosing an appropriate study environment, using appropriate note-taking strategies, choosing main ideas, and organization (Proctor et al., 2006).

An increasing number of college courses are delivered online, especially with the use of synchronous technologies, which provides an opportunity for educators to search for the most suitable learning environments for students' study habits. According to the technology used, online settings can meet learners' needs. A wide variety of videos, images, animations, texts, audio, and so on can be shared and virtual presentation media can be created. In this sense, Sharpe and Benfield (2005) reviewed the experiences and study habits of e-learners in higher education in order to identify areas worthy of future investigation. They found some connections among habits and performances and suggested deeper investigation into eliciting the experiences, habits, and strategies of effective e-learners. So, recent developments in DL technologies have grabbed the attention of researchers regarding how pedagogical approaches are required to function within this framework.

Thus, there emerges a need to gain an insight into the requirements, expectations, study habits, and learning styles of learners before new environments are included in online courses in higher education.

\section{Purpose of the Study}

In their study, Akdemir and Koszalka (2008) reported that effective design of instruction for online learning is most likely related to the characteristics and study preferences of the learner, as it is in a classroom. In this context, some studies mostly 
focused on attitudes towards learning environments or engagement in the learning environments (Simpson \& Yunfei, 2004; Popescu, 2010). Only a few studies focused on the preferences and performances of learners (Richmond \& Liu, 2005). Thus, the purpose of this study was to explore the relationship between students' learning styles and study habits in accordance with their learning styles in an online distance learning environment. Sub-problems were related to the connection between Kolb's learning styles, study habits of distance learners, and their learning performances. This would provide an insight into the satisfactory features of a synchronous setting for various learning styles and study habits and the requirements of the setting for quality instruction.

The research questions were as follows:

- What is the relationship between learning styles, study habits, and learning performances in an online learning environment?

- Do learning styles and study habits effect differently learners who have different learning performances?

This paper also provides suggestions about how Kolb's learning styles may be used and how learners' study habits may be taken into consideration in online learning environments.

\section{Study Framework}

In this study Kolb's learning cycle model was used as a framework for determining learning styles (shown in Figure 1). These four learning cycles are associated with learning styles. For instance, a converger favors the learning cycle of abstract conceptualization and active experimentation.

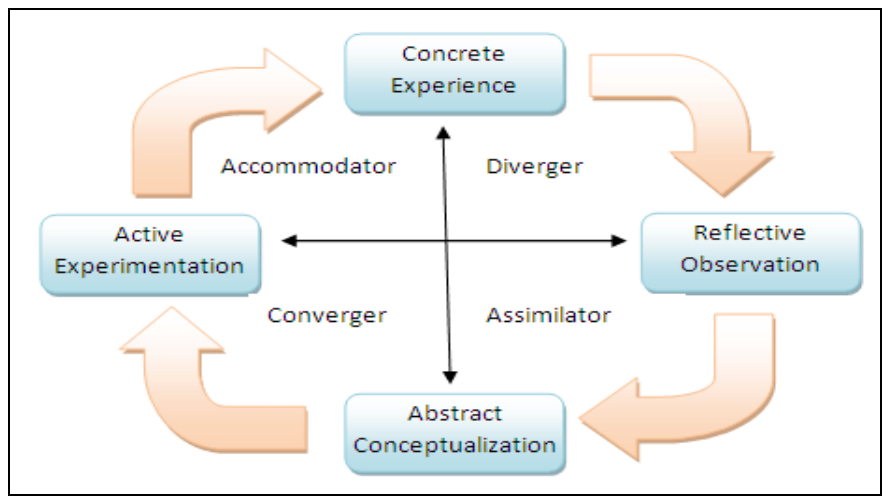

Figure 1. Kolb's learning cycle model (Kolb, 1985).

Healey and Jenkins (2000) and Manochehr (2006) worked on Kolb's learning cycle model and enhanced it with relationships among learning styles, learning conditions, 
and conditions where learners can learn best. The learning styles and conditions are shown in Table 1.

Table 1

Learning Styles and Conditions (Manochehr, 2006)

\begin{tabular}{lll}
\hline Learning style & $\begin{array}{l}\text { They learn best } \\
\text { through }\end{array}$ & Condition \\
\hline Diverger & Feeling and watching & $\begin{array}{l}\text { Learn when allowed to observe and } \\
\text { gather a wide range of information }\end{array}$ \\
Assimilator & Thinking and watching & $\begin{array}{l}\text { Learn when presented with sound } \\
\text { logical theories to consider } \\
\text { Learn when provided with practical } \\
\text { applications of concepts and theories } \\
\text { Learn when allowed to gain "hands on" } \\
\text { applications }\end{array}$ \\
\hline
\end{tabular}

The four learning styles are as follows:

- Assimilators have abstract conceptualization and reflective observation. They usually concentrate on the logical validity of theories, rather than focusing on their applicability.

- Accommodators choose to learn by doing and feeling. They learn best through concrete experimentation. They are intuitive and often study examples. They are more likely to be observers than activists.

- Convergers choose to make use of abstract conceptualization as well as active experimentation. Those who learn in this way are quite able to attain success in the practical application of ideas and theories, solving problems and making decisions.

- Divergers learn best through concrete experience and reflective observation. Their imaginative ability is strong. They tend to be people-oriented and react with emotions.

This study is based on Kolb's learning cycle and study habits framework outlined in Figure 2. 


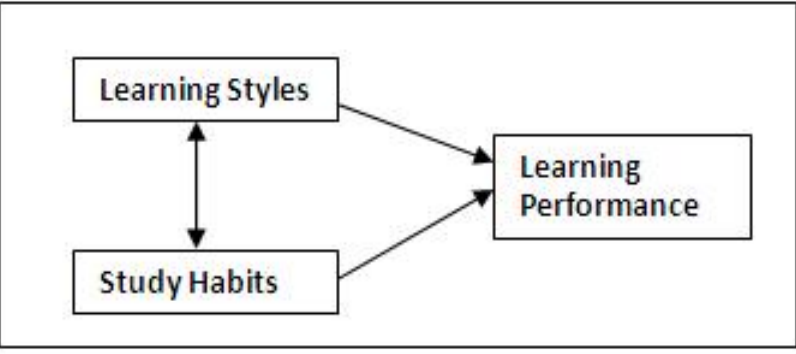

Figure 2. Study framework.

\section{Method}

\section{Instruments}

In order to meet the research questions, a Turkish version of Kolb's Learning Style Inventory (LSI-T), Study Habits Inventory (SHI), and Achievement Test (AT) were used in this study.

LSI-T: In this study LSI-T was administered before the intervention and after the final examination. The inventory is a 12 item questionnaire appropriate for teens and adults. Each item has four answers, which are ranked by the respondents in terms of best fit on a scale of 1 to 4 ( 4 = best). It was based on Kolb's learning styles: converging (abstract, active), diverging (concrete, reflective), assimilating (abstract, reflective), and accommodating (concrete, active). LSI was adapted into Turkish and validated by Aşkar and Akkoyunlu (1993) with the internal reliability high, Cronbach's alpha between .88 and .73. The LSI was administered to the participants in enough time by giving them the necessary explanations in advance. Responses were analyzed by organizing them into two bipolar concepts: concrete experience (CE) versus reflective observation (RO) and abstract conceptualization (AC) versus active experimentation (AE) (Aragon, Johnson, \& Shaik, 2002). The given scores for $\mathrm{CE}, \mathrm{AC}, \mathrm{RO}$, and $\mathrm{AE}$ were summed and then $\mathrm{AE}-$ $\mathrm{RO}$ and $\mathrm{AC}$ - CE were calculated to determine learners' ultimate learning styles. The scoring ranks of one dimension were dependent on how a participant was measured relative to scores from other dimensions.

SHI: Study habits of the learners were found with the opinions of students on a fivepoint Likert scale. James and Gardner (1995) addressed three important factors about selecting an instrument for determining learning styles: defining the intended use of the data to be collected, matching the instrument to the intended use, and selecting the most appropriate instrument. In the study habits dimension, frequently used inventories include Learning and Study Skills Inventory (Weinstein \& Palmer, 2002) and Inventory of Learning Processes (Schmeck, Geisler-Brenstein, \& Cercy, 1991). Though they have some common items, they deal with study habits from different 
dimensions. Thus with the help of previous studies a new inventory was developed for this study.

While developing the SHI, the studies (Crede \& Kuncel, 2008; Göğüş \& Güneş, 2011) taken as a basis included theoretical considerations, or qualitative analyses of the ways used by students study habits inventories. Eighty-one learners were asked to identify their study habits, such as which way of studying helped their understanding and their activities during the study process. The participants were different ages and from different socio-cultures. In order to build up the SHI, statements were chosen from the most commonly used ones. Then the items were classified in Patel's (1976) study habits categorization: planning work, reading, note taking, subject planning, concentration, exam preparation, typical habits, and typical school environment habits.

AT: AT was used for assessing the students' learning performances. It was conducted as pretests and posttests with respect to the content of an introductory programming course. In order to evaluate the students' achievement scores, mid-term exam scores and the final projects were graded and calculated. The mid-term score refers to an exam on the computer that tests the students' practical programming capability. The final exam included eight questions regarding introductory programming, including basic data structures, memory iteration, conditional statements, loops, recursive functions, procedures, and functions and problem solving. The achievement scores were calculated using the sum of $20 \%$ of the project scores as well as the scores for the mid-term examinations (30\%), and the grades for the final project (50\%). In addition, the author who was also the instructor interpreted his observations during the process in terms of learning styles and study habits.

\section{Participants}

Participants of the study included 66 sophomore students from a Turkish faculty of education, in a computer teacher training program. At the beginning of the study, LSI-T was used for categorizing learners' learning styles, shown in Table 2.

Table 2

Participant's Learning Style

\begin{tabular}{|c|c|c|c|c|c|c|c|c|c|}
\hline Gender & Total & \multicolumn{2}{|c|}{ Converger } & \multicolumn{2}{|c|}{ Assimilator } & \multicolumn{2}{|c|}{ Accommodator } & \multicolumn{2}{|c|}{ Diverger } \\
\hline & $\mathrm{n}$ & $\mathrm{n}$ & $\%$ & $\mathrm{n}$ & $\%$ & $\mathrm{n}$ & $\%$ & $\mathrm{n}$ & $\%$ \\
\hline Female & 24 & 9 & 37.5 & 6 & 25 & 5 & 20.8 & 4 & 16.6 \\
\hline Male & 42 & 16 & 38 & 13 & 30.9 & 7 & 16.6 & 6 & 14.3 \\
\hline Total & 66 & 25 & 37.8 & 19 & 28.7 & 12 & 18.1 & 10 & 15.2 \\
\hline
\end{tabular}




\section{Process}

The introductory programming language course was delivered online both in synchronous and asynchronous settings. The synchronous setting serves desktop sharing, video sharing, audio, verbal chat, presentation, whiteboard, online survey functions. Moreover, video records of the courses were saved in the system for participants to use asynchronously. The instructor presented the content during synchronous sessions, and discussed students' questions. Basic problems in the introductory programming course examples were discussed, and experts' sample programming codes were delivered to the students.

\section{Results}

The results of this study are presented in two sections: results from LSI-T and results from SHI with the correlations between learning styles and study habits and learning performances.

\section{Learning Styles}

The findings from descriptive statistics on average scores of the students with different learning styles are shown in Table 3.

Table 3

Average Scores of Four Learning Style Groups

\begin{tabular}{llll}
\hline Groups & $\mathrm{n}$ & $\mathrm{X}$ & $\mathrm{sd}$ \\
\hline Convergers & 25 & 45.32 & 24.77 \\
Assimilators & 19 & 48.1 & 22.86 \\
Accommodators & 12 & 67.25 & 18.78 \\
Divergers & 10 & 68.1 & 19.88 \\
\hline
\end{tabular}

ANOVA was conducted to determine whether there were significant differences among the average scores of four groups (assimilators, convergers, accommodators, divergers). The results of ANOVA are provided in Table 4. 
Table 4

ANOVA Results between Average Scores of the Four Learning Style Groups

\begin{tabular}{llllll}
\hline & $\begin{array}{l}\text { Sum of } \\
\text { squares }\end{array}$ & $\mathrm{df}$ & Mean square & $\mathrm{F}$ & $\mathrm{p}$ \\
\hline Between groups & 6625.878 & 3 & 2208.626 & 4.337 & .008 \\
Within groups & 31572.379 & 62 & 509.232 & & \\
Total & 38198.258 & 65 & & & \\
\hline
\end{tabular}

It is indicated with $\mathrm{p}$ value $(<.05)$ that there is a statistically significant difference among the average scores of these four groups. In order to determine the source of the significant differences, the Tukey test was conducted. Results of the Tukey test are shown in Table 5.

Table 5

Tukey HSD Test Results among Four Learning Style Groups

\begin{tabular}{lllll}
\hline Groups & Groups & $\begin{array}{l}\text { Mean } \\
\text { difference }\end{array}$ & Std. error & $\mathrm{p}$ \\
\cline { 2 - 5 } Convergers & Assimilators & -2.78526 & 6.86811 & .977 \\
& Accommodators & $-21.93000^{*}$ & 7.92498 & .036 \\
& Divergers & $-22.78000^{*}$ & 8.44349 & .043 \\
\cline { 2 - 5 } Assimilators & Convergers & 2.78526 & 6.86811 & .977 \\
& Accommodators & -19.14474 & 8.32092 & .109 \\
& Divergers & -19.99474 & 8.81617 & .117 \\
\cline { 2 - 5 } Accommodators & Convergers & $21.93000^{*}$ & 7.92498 & .036 \\
& Assimilators & 19.14474 & 8.32092 & .109 \\
& Divergers & -.85000 & 9.66226 & 1.000 \\
\cline { 2 - 5 } Divergers & Convergers & $22.78000^{*}$ & 8.44349 & .043 \\
& Assimilators & 19.99474 & 8.81617 & .117 \\
& Accommodators & .85000 & 9.66226 & 1.000 \\
\hline
\end{tabular}

The Tukey's HSD test has demonstrated that the accommodators had significantly higher average scores than those of the convergers. In addition, the divergers had significantly higher average scores than those of the convergers with a .05 level of significance. The other comparisons were not found significant. Another analysis was done according to the average scores. In this analysis the students were separated into three sub-groups according to the learning performances (poor: 0-45, average: 46-69, good: 70+), within all of the groups. The average scores of the groups based on their learning styles is shown in Table 6. 
Table 6

Average Scores of Four Learning Style Groups and their Sub-Groups

\begin{tabular}{llllllllllllcc}
\hline & \multicolumn{3}{c}{ Converger } & \multicolumn{3}{c}{ Assimilator } & \multicolumn{3}{c}{ Accommodator } & \multicolumn{3}{c}{ Diverger } \\
\hline $\begin{array}{l}\text { Sub- } \\
\text { groups }\end{array}$ & $\mathrm{n}$ & $\%$ & $\mathrm{X}$ & $\mathrm{n}$ & $\%$ & $\mathrm{X}$ & $\mathrm{n}$ & $\%$ & $\mathrm{X}$ & $\mathrm{n}$ & $\%$ & $\mathrm{X}$ \\
Poor & 9 & 45 & 15.1 & 7 & 35 & 21.4 & 2 & 10 & 37.5 & 2 & 10 & 37.5 \\
Average & 10 & 40 & 55.3 & 7 & 28 & 56.1 & 5 & 20 & 62.6 & 3 & 12 & 60. \\
& & & & & & & & & & & & 5 \\
Good & 6 & 28.5 & 74 & 5 & 23. & 74.2 & 5 & 23. & 83.8 & 5 & 23. & 80. \\
& & & & & 8 & & & 8 & & & 8 & 8 \\
Total & 25 & 37.8 & 45.3 & 19 & 28.7 & 48.1 & 12 & 18.1 & 67.2 & 10 & 15.1 & 68.1 \\
\hline
\end{tabular}

\section{Study Habits}

A survey was provided in order to reveal study habits which ranged from strongly agree $=5$ to strongly disagree $=1$. Mean values $(\mathrm{X})$ and the standard deviations $(\mathrm{SD})$ of the items are provided in Table 7.

Table 7

Study Habits Average Scores and Standard Deviations of Sub-Groups

\begin{tabular}{lllllll}
\hline Study habits & \multicolumn{2}{l}{ Poor $(\mathrm{n}=20)$} & \multicolumn{2}{l}{ Average $(\mathrm{n}=25)$} & \multicolumn{2}{l}{ Good $(\mathrm{n}=21)$} \\
\hline & $\mathrm{X}$ & $\mathrm{SD}$ & $\mathrm{X}$ & $\mathrm{SD}$ & $\mathrm{X}$ & $\mathrm{SD}$ \\
Home environment and planning of work & 20.6 & 3.31 & 23.64 & 4.32 & 24.85 & 4.05 \\
Reading and note taking habit & 34.65 & 2.39 & 39 & 3.94 & 42.52 & 2.94 \\
Planning of subjects & 17.4 & 2.60 & 20.52 & 2.02 & 21.33 & 2.3 \\
Habits of concentration & 12 & 1.94 & 13.08 & 0.91 & 15.33 & 2.3 \\
Preparation for examination & 15.7 & 2.71 & 17.12 & 1.74 & 18.14 & 1.35 \\
General habits and attitudes & 31 & 6.1 & 38.32 & 4.16 & 45.47 & 5.42 \\
School environment & 39.7 & 3.85 & 43.68 & 3.79 & 42.80 & 5.29 \\
\hline Overall study habits & 170.2 & 8.78 & 196.6 & 9.53 & 210.38 & 7.89 \\
\hline
\end{tabular}

Table 7 shows those "good" students' habits of concentration, and their reading as well as note taking habits, and general habits and attitudes are considerably higher than those of others. The preparation for examination habits of the "poor" and "average" students were ranked with a higher average score, while the home environment and planning of work habits of the "average" students feature with a higher score. To determine whether the three groups (good, average, and poor) have significant correlations between the study habit items and average scores of the groups, the 
correlations between the study habits and average scores are determined and provided in Table 8.

Table 8

Correlations between Study Habit Scores and Average Scores of the Sub-Groups

\begin{tabular}{llllll}
\hline & & \multicolumn{3}{c}{ Average Scores } \\
\hline Sh\# & Study habits & $\begin{array}{l}\text { All } \\
\text { students } \\
(\mathrm{r})\end{array}$ & $\begin{array}{l}\text { Good } \\
\text { students } \\
(\mathrm{r})\end{array}$ & $\begin{array}{l}\text { Average } \\
\text { students } \\
(\mathrm{r})\end{array}$ & $\begin{array}{l}\text { Poor } \\
\text { students } \\
(\mathrm{r})\end{array}$ \\
\hline Sh1 & Home environment and planning of work & $.444^{*}$ & .071 & .181 & .154 \\
Sh2 & Reading and note taking habit & $.624^{*}$ & .181 & .099 & .093 \\
Sh3 & Planning of subjects & $.548^{*}$ & $.515^{*}$ & $.318^{*}$ & $.433^{*}$ \\
Sh4 & Habits of concentration & $.487^{*}$ & $.402^{*}$ & .117 & $-.523^{*}$ \\
Sh5 & Preparation for examination & .373 & .253 & $.454^{*}$ & .070 \\
Sh6 & General habits and attitudes & $.714^{*}$ & $.295^{*}$ & .162 & .236 \\
Sh7 & School environment & $.327^{*}$ & .102 & .083 & $.455^{*}$ \\
\hline
\end{tabular}

* Correlation is significant at the 0.05 level (2-tailed).

The Pearson correlation (r) was assessed in accordance with Cohen (1998), classifying the $r$ values as $-1=$ perfect negative, $0.75-1.00=$ strong positive, $0.5-0.75=$ moderate positive, $0.25-0.5=$ weak positive, $-0.25-0.25=$ no linear association, $-0.5--0.25=$ weak negative, $-1--0.75=$ strong negative, $1=$ perfect negative. The Pearson correlation coefficient indicates a moderate positive correlation between Sh2, Sh3, Sh6, and All Students average scores. Hence, as Sh2, Sh3, Sh6 increases, average scores for all students will also increase. Sh1, Sh4, and Sh7 had a weak positive correlation among the average scores for all groups. For the "good" students, only Sh3 had moderate positive correlations with average scores of the good group. There were only two habits of the average group that have positive correlations with study habits, which are actually weak, with Sh3 and Sh5. The correlation coefficients between the poor students' average scores, Sh3 and Sh7, were weakly positive. Overall habits were calculated by means of the total habit scores of each study habit category. The correlations between the overall habits and average scores are provided in Table 9.

Table 9

Correlations between Overall Habits and Average Scores of Sub-Groups

\begin{tabular}{llccc}
\hline Study habits & $\begin{array}{l}\text { All } \\
\text { students } \\
(\mathrm{r})\end{array}$ & $\begin{array}{c}\text { Good } \\
\text { students } \\
(\mathrm{r})\end{array}$ & $\begin{array}{c}\text { Average } \\
\text { students } \\
(\mathrm{r})\end{array}$ & $\begin{array}{c}\text { Poor } \\
\text { students } \\
(\mathrm{r})\end{array}$ \\
\hline Overall habits & $.884^{*}$ & .108 & $.796^{*}$ & .544 \\
\hline
\end{tabular}


Correlations between the average scores for all students and overall habits as well as overall habits between the average scores of the "average" students were found to be strongly positive. Overall habits and good students' average scores as well as poor students' average scores were not significantly correlated.

\section{Discussion}

\section{Learning Styles of Distance Learners}

It can be suggested that the leading learning style was the convergers, where students typically choose to learn through practical applications, including solving problems, trying to make correct decisions, and preferring to work with technical works or problems, rather than working with social relations. Convergers were followed by the assimilators, who concentrate on abstract concepts, make reflective observations, and assimilate them into an integrated explanation. The accommodators and the divergers were close in that they rarely choose to learn through conducting experiments, taking risks (accommodators), and producing new ideas, observing the situations from different perspectives, and bringing different ideas together (divergers). Although the number of the divergers was the lowest, this group achieved the highest score of average scores. This is similar to Karademir and Tezel (2010), who found that Turkish university students are generally accommodators, and divergers are fewer in number than others.

The divergers had higher average scores and learn better through feeling and watching. This may be because they watched the samples and they have a good command of the details of this observation. The results were similar to Daniel's (1999) finding that divergers preferred reflective observation (watching), and achieved significantly higher scores. In fact, it has been stated with respect to the characteristics of divergers that they "learn when allowed to observe and gather a wide range of information" (Manochehr, 2006). They view concrete situations from many perspectives and adapt those by observation, rather than by action. In this sense, it can be concluded that, particularly in a synchronous setting, it contributes to the understanding of their problem solving styles that they see the programming examples, while the instructor is presenting them. In addition, students could also follow the records of lesson videos asynchronously which might have allowed them to bring forward their observation abilities.

The students adopting a "diverger" learning style were followed by the "assimilator", "accommodator", and "converger" learning styles, respectively. In contrast to this study, $\mathrm{Lu}$, et al. (2007) found no significant effect between Kolb learning styles and learning outcomes and the study results showed that the mean of learning outcomes of convergers and assimilators was higher than that of divergers and accommodators. In this sense, Sun et al. (2008) have observed that the experimental group making use of 
the online activities was not considerably different from the students with different learning styles. They found that the accommodators gained the most significant achievements. The results of this study are confirmed by some studies but also have differences from others.

In addition, in this study students usually studied with short size programming examples which were not difficult to follow. The instructor provided the major statements related to the subject before presenting the examples and students were allowed to make reviews on the concrete experiences. In this sense, the description of programming by means of illustration and exercise showed a positive correlation with the divergers' focusing on concrete experiences. Also, students' cooperative brainstorming on their assignments or projects shows that there is an emphasis on social interaction. Looking at their average scores, the divergers were followed by the accommodators. This group of students learns through "feeling" and "doing". They were good at adapting to changed circumstances and they solved the problems in the homework given by the instructor intuitively. They usually choose to learn through selfanalyzing such as trial and error and discovery learning. Although Shaw (2012) in his study on learning programming in online forums as well as Wang, et al. (2011) have emphasized that when learning how to program, it is essential that the practices of the students verify an important conclusion that actual practice in the programming language learning is superior to just watching information. The enhanced features of the synchronous system used in this study might create a monitoring and follow-up environment far beyond the simple online forum and contribute to the learning performance of the students. On the other hand, the common feature of "feeling" in the groups of divergers and accommodators shown in Table 10 indicates that the feature of "feeling" can be of importance in synchronous settings. The assimilators and convergers have a common feature of "thinking". The convergers are those who choose to learn through practical applications of concepts, and most of the students in the class adopted this style. These students like decision making, problem solving, and the practical application of ideas. It is interesting that convergers had lower average scores in the programming course, which consists of problem solving, although these students adopted problem solving and learn this way. In addition, the assimilators, who learn through demonstration, have the lowest average scores; however, a significant number of students choose this learning style. These students incorporate a number of different observations and thoughts into an integrated whole. In fact, it is emphasized that programming can be understood during a lecture; however, writing programming codes required different features (Robins, Rountree, \& Rountree, 2003). Although the concentration of the divergers and accommodators with higher average scores on the concrete structures is an important common feature, it is interesting that the assimilators and the convergers most commonly preferred among the distance learners focus on abstract structures. The divergers show reflective characteristics, while the accommodators with a close average to the divergers choose to be actively involved in learning. Similarly, the assimilators adopt a reflective learning style, while the convergers adopt an active learning style. In this sense, it is seen that the active 
involvement in learning would not have a considerable effect on learningprogramming in an online synchronous setting. Although Dringus and Terrell (2000) and Lippert, Radhakrishna, Plank, and Mitchell (2001) in their studies based on Kolbs's LSI found that learning style had no effect on success in online learning, this study provides some evidence that styles may be important while benefiting from various online learning technologies or may be effected by teaching strategies.

In this study, students were separated as poor, average, and good based on the pretest results. Among the poor students, the average scores of the accommodators and divergers were equivalent (37.5), and these scores were higher than those of the convergers (15.1) and the assimilators (21.4). Among the average students, the accommodators have the highest average scores, while the number of the students in this group was the lowest. The ranging of average scores as accommodators, divergers, assimilators, and convergers among the average students was the same for the good students. Considering all three groups, it is seen that the accommodators and the divergers had higher average scores than those of the convergers and the assimilators. At this point, it is quite interesting that the number of students in the groups of the accommodators and the divergers were low within each of three poor, average, and good groups.

Especially in the studies conducted among Turkish university students, it can be seen that the numbers of the divergers and the accommodators have a small share among the participants involved in the studies (Akkoyunlu \& Soylu, 2008). Similarly, this study addresses some new data which were the same for online learning. The correlations between the learning styles and the average scores were also an important result of this study. This relationship is summarized in Table 10.

Table 10

Relationships between Average Scores and Four Learning Styles

\begin{tabular}{|c|c|c|c|c|}
\hline \multirow{2}{*}{$\begin{array}{l}\text { Average } \\
\text { scores } \\
\end{array}$} & \multicolumn{4}{|c|}{ Features of learning styles } \\
\hline & Feeling & Watching & Thinking & Doing \\
\hline $\begin{array}{l}\text { High average } \\
\text { scores }\end{array}$ & $\begin{array}{l}\text { Diverger } \\
\text { Accommodator }\end{array}$ & Diverger & & Accommodator \\
\hline $\begin{array}{l}\text { Low average } \\
\text { scores }\end{array}$ & & Assimilator & $\begin{array}{l}\text { Assimilator } \\
\text { Converger }\end{array}$ & Converger \\
\hline
\end{tabular}

The "doing" learning style was associated with nearly the same performance as the "watching" learning style because the divergers (watching) have higher average scores, while the average scores of the students adopting another learning style (assimilator) with watching had a lower average score. Similarly, students adopting the 
accommodator learning style featured with "doing" had higher average scores than other students adopting the "doing" feature.

As a result, in this study, it has been asserted that there is a significant relationship between the learning style and the average scores as learning performances. In this sense, Mitchell (2000) concluded that learning style may be an important indicator of how effectively different instructional strategies can be applied for different types of learners enrolled in online courses. So, the findings of this study can be considered as evidence that learning styles can be an indicator for success in online courses carried out through an online synchronous system as an enhanced version of a DL course.

\section{Study Habits of Distance Learners}

Results showed that the average study habit scores (SHS) were all ranged as $\mathrm{SHS}_{\text {poor }}<$ $\mathrm{SHS}_{\text {average }}<\mathrm{SHS}_{\text {good }}$. This reflects good students had better SHS scores than those of the other groups. Only the "school environment" category was ranged as $\mathrm{SHS}_{\text {average }}>$

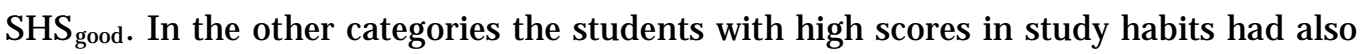
high average scores. For "overall habits" consisting of the total of seven study habits, the "good" students had also the highest SHS, and they were followed by the overall SHS of the "average" students. Additionally, the SHS of the "good" and "average" students were higher than those of the "poor" students. The results of the sub-groups' academic achievements confirms the idea of Gögüs and Güneş (2011) that academic performances increased when students used effective study habits in online learning settings. In this sense, Robinson (2000) also found that certain bad study habits resulted in poor learning performance.

It is interesting that the average scores and the planning of subjects scores of the "good" students have a moderate positive correlation, and that there was a moderate negative correlation between the average habits of concentration scores and average scores of the "poor" students. A weak or a moderate positive correlation between the planning of subject and the average scores of each of the three groups (poor, average, good) suggest that it is also important for the students to plan the subjects in a synchronous setting. As is generally known, a programming course has a typically inductive conceptual structure; it is important to study by planning the subjects in order to achieve higher learning performance. This situation was also the same in the online environment. There was a positive correlation between the habits of concentration of "good" students, and a negative correlation between the average scores of the "poor" students. It is particularly difficult to enable concentration in online synchronous settings because learners are carefully following the course as they do not know when the instructor will ask a question and where the instructor will indicate something. In addition, it is known that there are many factors at home or at work that may disturb the concentration of distance learners. The missing parts of the lessons can be watched asynchronously through video records. However the body language of the instructor during the lecture cannot be felt which is important for the students' concentration during the lesson. It is interesting that none of the habits of preparation for the examination, reading and note 
taking and home environment, is correlated with the average scores in all groups. Although note taking is a most usable feature for the programming course in a class environment, it is not mostly preferred in the synchronous lessons. Maybe students didnot want to miss the presentation of the instructor by spending extra time to take notes. Time management is an important issue in DL and some researchers consider it as a major concern for online students (McEwen, 2001).

Some authors suggest following the examples given during the online courses, rather than the short-term exam studies, in the programming course (Robins, Rountree, \& Rountree, 2003). In this study, even if there were different exam preparation habits, they did not affect the average scores. As students follow the course from different environments (home, work, dorm, etc.) in distance education, naturally there emerge different environments during the active course hours. Although students' study environment at home was different, and they had different family features, the impact of these features on the learning performances in this course was not significant.

It may be concluded that the impacts of two study habits, planning and concentration, were prominent. Planning is related to organization and concentration is related to feeling. Planning is generally about the nature of the course and concentration is about the nature of the online synchronous setting. Considering all study habits together, some considerations can be presented that the students with positive study habits have higher average scores, and some habits may have an impact on the learning performances in the online synchronous settings, not entirely but in this aspect. It can be thought that the features (visual, audio, texts, animations, etc.) provided by the online synchronous settings might affect the development of positive study habits. In addition, the methods of the instructor's presentation can be considered as a factor playing a role in the development of positive habits. Hence Ally and Fahy (2002) concluded that in the online learning environments e-teachers must provide adequate support strategies for students with different learning styles.

\section{Conclusions}

The results of this study showed significant relationships between the students' learning styles, study habits, and performances in online learning, and have offered an insight into the mode of delivery. The design of effective courses for distance learners is most likely to be in connection with the characteristics and preferences of the learner, as it is in the classroom. It was seen that the learners usually show characteristics of assimilators in online synchronous settings. However, the results have shown that the "divergers and accommodators" styles were associated with higher learning scores in synchronous settings. Another common characteristic of the good students was "feeling" according to the results of this study. So I suggest this for programming language learning, with online synchronous settings, and the students' active involvement to have positive feelings and to improve their learning performances. 
It was found that there is a significant correlation between the two study habits (concentration and planning of subjects). Considering that it is difficult to control concentration in online synchronous settings, it is deemed necessary for the instructors and the environment designers to take special measures in this respect. The planning of work is not an easy task for distance learners to perform. At this point, instructors can announce their syllabus which may provide support for these students at the beginning of the terms. Hence, learning performances can be enhanced with measures to easily bring forward study habits for distance learners. In this study, home environment and planning of work, reading, and note taking habits do not have a significant correlation with academic achievement in online synchronous settings. In particular, it is quite difficult to apply note taking habits due to the nature of the online synchronous setting. At this point, it may be proper for instructors to highlight the course records and to direct the students to watch these records.

Learning styles and study habits not only indicate how learners learn, but they can help an instructor support individual students, so that they might teach successfully (Tseng, Chu, Hwang, \& Tsai, 2008). The results can help instructors get to know and use different tools for different learning styles and study habits to increase the performance of the students. As Mupingo, Nora, and Yaw (2006) state some of the online classes may have an unknown make-up so the characteristics of online students may be unclear which makes it difficult to develop effective online courses. An instructor should take into account all the related factors and include the necessary components in the program when designing a synchronous course to facilitate student learning, through examination of the learning styles of the distance learners, various learner performances, and involvement in online environments. Considering the idea of Wolfe et al. (2006) using videos, chat rooms, whiteboards, discussion boards, and providing assignments to suit learners' preferences may enhance learners' academic performances.

In addition, Dağ and Geçer (2009) with their review stated that improving academic achievements in online learning not only involves learning styles but also motivation of the learner, demographic factors, teaching strategies, and teaching methods. Moreover, Gögüş and Güneş (2011) pointed out that study skills, time management skills, and learning habits exhibited strong relations with academic performance in online learning. Thus, administrating workshops and sessions may help students to develop appropriate study habits for the nature of the teaching strategies and technologies used.

At the institutional level in particular, institutions that want to transfer some of their conventional courses onto the web may grasp the differences among students' learning styles in creating flexible instructional strategies that allow for synchronous settings. For future studies, it is recommended that some new correlations can be assessed between learning styles and study habits, regardless of whether the learning styles may be effective in controlling study habits in online learning environments. 
In conclusion, this study showed that matching learning styles and study habits with teaching methods will serve academic performance. Some inventories should be administered at the beginning of the course so that course design and structure may be designed and implemented accordingly. This study was mostly directed to learning styles and study habits individually. Future research may examine common effects of learning styles and study habits together on academic performances. 


\section{References}

Akdemir, O., \& Koszalka, T. A. (2008). Investigating the relationships among instructional strategies and learning styles in online environments. Computers \&Education, 50(4), 1451-1461.

Akkoyunlu, B., \& Soylu, M. Y. (2008). A study of student's perceptions in a blended learning environment based on different learning styles. Educational Technology \& Society, 11(1), 183-193.

Allen, M., J . Bourhis, N. Burrell, \&E. Mabry. (2002). Comparing student satisfaction with distance education to traditional classrooms in higher education: A metaanalysis. The American J ournal of Distance Education, 16(2), 83- 97.

Ally, M., \& Fahy, P. (2002, August). Using students' learning styles to provide support in distance education. In Proceedings of the Eighteenth Annual Conference on Distance Teaching and Learning, Madison, WI.

Aragon, S. R., J ohnson, S. D., \& Shaik, N. (2002). The influence of learning style preferences on student success in online versus face-to-face environments. The American J ournal of Distance Education, 16(4), 227-243.

Aşkar, P., \& Akkoyunlu, B. (1993). Kolb learning style inventory. Education and Science, 15(81), 37-47.

Benbunan-Fich, R., \&S. R. Hiltz. (2003). Mediators of the effectiveness of online courses. IEEE Transactions on Professional Communication, 46(4), 298- 312.

Chen, N. S., \& Lin, K. M. (2002, September). Factors affecting e-learning for achievement. In IEEE International Conference on Advanced Learning Technologies ( 9-12).

Coffield, F., Moseley, D., Hall, E., \&Ecclestone, K. (2012). Learning styles and pedagogy in post-16 learning: A systematic and critical review. Learning and Skills Research Centre: London.

Cohen, J . (1988). Statistical power analysis for the behavioral sciences (2nd ed.) Hillsdale, NJ : Lawrence Erlbaum Associates.

Coleman, P., Collinge, J ., \& Tabin, Y. (1993). The Learning triad: Parental involvement. London: University of North London Press.

Crede, M., \& Kuncel, N. R. (2008). Study habits, skills, and attitudes: The third pillar supporting collegiate academic performance. Perspectives on Psychological Science, 3, 425-454. 
Dağ, F., \& Geçer, A. (2009). Relations between online learning and learning styles. Procedia-Social and Behavioral Sciences, 1(1), 862-871.

Daniel, J . A. (1999). Effects of learning style and learning environment on achievement of physical therapy graduate students in distance education (Doctoral dissertation). Texas Tech University.

Dringus, L., \& Terrell, S. (2000). An investigation of the effect of learning style on student success in an online learning environment. J ournal of Educational Technology Systems, 28(3), 231-238.

Dunn, R., \& Dunn, K. (1978). Teaching students through their individual learning styles: A practical approach. Reston, VA: Reston Publishing.

Dziuban, C., Moskal, P., \& Hartman, J . (2005). Higher education, blended learning, and the generations: Knowledge is power: No more. Elements of quality online education: Engaging communities. Needham, MA: Sloan Center for Online Education.

Fahy, P. J ., \&Ally, M. (2005). Student learning style and asynchronous computermediated conferencing (CMC) interaction. The American J ournal of Distance Education, 19(1), 5-22.

Fearing, A., \& Riley, M. (2005). Graduate students' perceptions of online teaching and relationship to preferred learning styles. Medsurg Nursing, 14(6), 383- 389.

Federico, P. A. (2000). Learning styles and student attitudes toward various aspects of network-based instruction. Computers in Human Behavior, 16(4), 359-379.

Felder, R. M., \& Silverman, L. K. (1988). Leaming and teaching styles in engineering education. Engineering Education, 78(7), 674-681.

Felder, R. M., \& Soloman, B. A. (1997). Index of learning styles. Retrieved from http:// www.ncsu.edu/ felder-public/ ILSpage.html

Fleming, N. D. (2001). Teaching and learning styles: VARK Strategies. Honolulu Community College.

Gardner, H. (1993). Multiple intelligences: The theory into practice. New York: Basic Books.

Göğüş, A., \& Güneş, H. (2011). Learning styles and effective learning habits of university students: a case from Turkey. College Student J ournal, 586-600

Gregorc, A. F. (1984). Gregorc's style delineator: Development, technical, and administration manual. Gregore Associates, Inc. 
Gregorc, A. F., \& Butler, K. A. (1984). Learning is a matter of style. VocEd, 59(3), 27-29.

Hamilton-Pennell, C. (2002). Getting ahead by getting online. Library J ournal, 127(19), 32-35.

Healey, M., \&J enkins, A. (2000). Learning cycles and learning styles: the application of Kolb's experiential learning model in higher education. J ournal of Geography, 99(5), 185-195.

Honey, P., \& Mumford, A. (1986). Using your learning styles (2nd ed.). Maidenhead,, UK: Peter Honey.

Hummel, H. G.-K. (2006). Feedback model to support designers of blended-learning courses. International Review of Research in Open and Distance Learning, 7(3), 1- 16.

James, W. B., \& Gardner, D. L. (1995). Learning styles: Implications for distance learning. New Directions for Adult and Continuing Education, 1995(67), 19-31.

J onassen, D. H., \& Grabowski, B. L. (2012). Handbook of individual differences learning and instruction. Routledge.

J ung, C. G. (1970). Analytical psychology, theory and practice, the Tavistock lectures. New York: Vintage Books.

Karademir, E., \&Tezel, Ö. (2010). Examination of the learning styles of pre-service elementary teachers in terms of demographic variables. Pamukkale University Faculty of Education J ournal, 28, 129-145.

Kolb, A. Y., \& Kolb, D. A. (2005). Learning styles and learning spaces: enhancing experiential learning in higher education. Academy of Management Learning \&Education, 4(2), 193-212.

Kolb, D. A. (1985). Learning Style Inventory: Self Scoring Inventory and interpretation booklet. Boston: McBer and Company.

Liegle, J . O., \&J anicki, T. N. (2006). The effect of learning styles on the navigation needs of Web-based learners. Computers in Human Behavior, 22(5), 885-898.

Lippert, R. M., Radhakrishna, R., Plank, O., \& Mitchell, C. C. (2001). Using different evaluation tools to assess a regional internet in-service training. International J ournal of Instructional Media, 28(3), 237-248.

Lu, H., Jia, L., Gong, S. H., \& Clark, B. (2007). The relationship of Kolb learning styles, online learning behaviors and learning outcomes. J ournal of Educational Technology \& Society, 10(4). 
Manochehr, N.N. (2006). The influence of learning styles on learners in e-learning environments: An empirical study. Cheer Virtual Edition, 18, 10-14.

McEwen, B. C. (2001). Web-assisted and online learning. Business Communication Quarterly, 64(2), 98-103.

Miller, L. M. (2005). Using learning styles to evaluate computer-based instruction. Computers in Human Behavior, 21(2), 287-306.

Mitchell, J . L. (2000). The effect of matching teaching style with learning style on achievement and attitudes for women in web-based distance education course. Terre Haute, IN: Indiana State University.

Morris, K. V., Finnegan, C., \& Sz-Shyan, W. (2005). Tracking student behavior, persistence, and achievement in online courses. Internet and Higher Education, 8(3), 221- 231.

Mupingo, D. M., Nora, R. T., \&Yaw, D. C. (2006). The learning styles, expectations, and needs of online students. College Teaching, 54(1), 185-189.

Neuhauser, C. 2002. Learning style and effectiveness of online and face-to face instruction. The American J ournal of Distance Education, 16(2), 99- 113.

Patel, B. V. (1976). Study habits inventory. In D. M. Pestonjee, (Ed.), Second handbook of psychology and social instruments. Concept Publishing Company, New Delhi.

Popescu, E. (2010). Adaptation provisioning with respect to learning styles in a Webbased educational system: An experimental study. J ournal of Computer Assisted Learning, 26, 243- 257.

Proctor, B. E., Prevatt, F., Adams, K., Reaser, A., \& Petscher, Y. (2006). Study skills profiles of normal-achieving and academically struggling college students. The J ournal of College Student Development, 47, 37-51

Richmond, A. S., \& Liu, L. (2005). Student learning styles of traditional courses versus online distance courses. In C. Crawford, R. Carlsen, I. Gibson, K. McFerrin, J . Price, R. Weber \&D. A. Willis (Eds.), Technology \& teacher education annual (pp. 576-578). Charlottesville, VA: AACE.

Robins, A., Rountree, J . \& Rountree, N. (2003). Learning and teaching programming: a review and discussion. Computer Science Education, 13, 137-173.

Robinson, H. H. (2000). Effective study. New York: Harper and Brothers. 
Schellens, T., \& M. Valcke. 2000. Re-engineering conventional university education: Implications for students' learning styles. Distance Education, 21(2), 361- 384.

Schmeck, R. R., Geisler, E., \& Cercy, S. P. (1991). Self-concept and learning: The revised inventory of learning processes. Educational Psychology, 11, 343-362.

Sharpe, R., \& Benfield, G. (2005). The student experience of e-learning in higher education. Brookes eJ ournal of Learning and Teaching, 1(3).

Shaw, R.S. (2012). A study of the relationships among learning styles, participation types, and performance in programming language learning supported by online forums. Computers \&Education, 58, 111-120

Simpson, C., \&Yunfei, D. (2004). Effects of learning styles and class participation on students' enjoyment level in distributed learning environments. J ournal of Education for Library and Information Science, 45(2), 123-136.

Smith, P.L., \& Ragan, T. J . (1999). Instructional design (2nd ed.). USA: J ohn Wiley\& Sons, Inc.

Sun, K. T., Lin, Y. C., \&Yu, C. J . (2008). A study on learning effect among different learning styles in a Web-based lab of science for elementary school students. Computers \& Education, 50(4), 1411- 1422.

Terrell, S. (2002). Learning style as a predictor of success in a limited residency doctoral program. The Internet in Higher Education, 5(4), 345-352.

Tseng, C. R., Chu, H. C., Hwang, G. J ., \& Tsai, C. C. (2008). Development of an adaptive learning system with two sources of personalization information. Computers \& Education, 51(2), 776- 786.

Wang, K. H., Wang, T. H., Wang, W. L., \&Huang, S. C. (2006). Learning styles and formative assessment strategy: Enhancing student achievement in Web-based learning. J ournal of Computer Assisted Learning, 22(3), 207- 217.

Wang, T., Su, X., Ma, P., Wang, Y., \&Wang, K. (2011). Ability-training-oriented automated assessment in introductory programming course. Computers \& Education, 56(1), 220- 226.

Weinstein, C. E., \& Palmer, D. R. (2002). Learning and study strategies inventory (LASSI): User's manual (2nd ed.). Clearwater, FL: H \& H Publishing.

Wolfe, D. A., J affe, P. G., \& Crooks, C. V. (2006). Adolescent risk behaviors: Why teens experiment and strategies to keep them safe. New Haven, CT: Yale University Press. 


\section{Athabasca University $\mathbf{Z}$}

(c) (†) 